IRSTI 06.61 .33

UDC 332.1

https://doi.org/10.46914/1562-2959-2021-1-3-88-95

A.A. AMANBAEVA, ${ }^{* 1}$
PhD, Senior Lecturer.
*e-mail: asema.31.1983@mail.ru
M.K. TOLYMGOZHINOVA, ${ }^{2}$
c.e.s.
e-mail: maigylt@mail.ru
S.A.AZYLKANOVA, ${ }^{3}$
c.e.s.
e-mail: azsaule@mail.ru

TCHON LI KU, ${ }^{4}$

c.e.s., associate professor.

e-mail: tchonli@yahoo.com

${ }^{1}$ Kazakh Innovative University of Humanities and Law,

Kazakhstan, Semey

${ }^{2}$ Shakarim Semipalatinsk State University,

Kazakhstan, Semey

${ }^{3}$ Gumilyov Eurasian National University,

Kazakhstan, Nur-Sultan

${ }^{4}$ Yanka Kupala Grodno State University,

Belarus, Grodno

\title{
ANALYSIS AND EFFICIENCY EVALUATION OF INVESTMENTS RESOURCES ATTRACTION TO THE REGION
}

\begin{abstract}
The article presents a methodology for assessing the investment activity of the regions. The economic policy of the region at the macroeconomic level is implemented by the state through its governing bodies, legislative and executive bodies. At this high level, decisions on the development of the national economy and each region are made taking into account national interests. At the same time, it is necessary to consider the national economy not only as a whole, but also as a system that differs and works together in different aspects. In this system, regardless of the specific territory, they determine the production and economic potential of the whole country, its place in the world economic space, national economic security and the stability of the national economy. It is a militaryindustrial complex, competitive, large-scale scientific and high-tech industries, important cultural and social facilities. Regulation of the development of these facilities is the main direction of the state regional economic policy at the highest level. The national approach to the regulation of the regional economy is in the interests of ensuring social justice in the country as a whole. This, in turn, requires the development of special programs to improve the living standards of the population in socially disadvantaged areas for various reasons or to justify the decisions of major governments. Such programs have been developed in rural areas of Kazakhstan in the past, but some are not satisfied with their implementation.
\end{abstract}

Key words: economy, investment, region, special program, evaluation, analysis, development, regulation.

\section{Introduction}

The development of a state depends on its economy. Many projects are needed to implement the state plan. Funds are needed to implement projects. It is clear that the state cannot attract funds from the budget for the implementation of all these projects. Thus, there are currently no funds for the timely financing of all projects. Based on this, our state supports investors. It is clear that the support of investors will contribute to the development of the country. In this regard, investors need government support. It is obvious that the correct and sustainable implementation of this support in accordance with modern requirements will be the key to the development of our country. Several scientists have 
studied this issue in detail. The current policy of innovation capacity also requires funds from these investors. Investor support is a very important policy issue.

\section{Literature review}

The works of Russian and foreign researchers on many theoretical and practical issues on the subject can be noted: L. Abalkin, N. Kaftunkina, I. Balabanov, N. Kondratiev, K. Kireeva, E. Krolivetsky, D. Labin, M. Kulagin, L. Simkina, J. Worst, I. Firova, L. Gitman, P. Reventlow, M. Jonk, J. Keynes, M. Reiser, et al. Also, the views and opinions on this issue were expressed by M. Ashimbayev, U. Baimuratov et al. This is reflected in the works of Kazakhstani scientists.

\section{Methodology and results}

The purpose of state support for investment is to create a favorable investment environment for economic development and the creation of new industries, to expand and modernize existing industries using modern technologies, to improve the skills of the Kazakh workforce and to encourage investment in environmental protection [1].

State investment support consists of providing investment incentives.

State support for investments is carried out by accredited investment institutions designated by the Government of the Republic of Kazakhstan to conclude investment contracts and monitor their implementation.

In accordance with the laws of the Republic of Kazakhstan, there is a procedure for giving investment priority to investments, investment priorities and individual investment projects.

Investment priority is a benefit of the subject qualification provided under the laws of the Republic of Kazakhstan.

A corporation of the Republic of Kazakhstan carrying out an investment project, a company that leases a company that imports technical equipment as part of an investment project on the basis of a financial lease agreement of a corporation of the Republic of Kazakhstan carrying out an investment project [2].

Legal entities of the Republic of Kazakhstan - legal entities established under the laws of the Republic of Kazakhstan, including foreigners.

Investment projects offer the following investment preferences:

- Exemption from customs duties and VAT on imports

- Grants in kind - The maximum amount of grants in kind does not exceed 30\% of the investment in fixed assets (land, buildings, structures, machinery and equipment, computers, measuring and technical tools) of legal entities of the Republic of Kazakhstan. and devices, vehicles (automobiles), production and household equipment).

Tax exemption is provided in the form of investment preferential treatment for individual investment projects (hereinafter referred to as investment preferential treatment for individual investment projects).

Import duties and taxes according to the tax laws of the Republic of Kazakhstan.

As the Akmola region is suitable for agriculture, attracting investment in agriculture is one of the top investment projects in the region.

When studying economic growth factors, a common factor of growth is characterized by an increase in resources. Rapid growth drivers, production scale and resource efficiency will increase.

To study the effect of key growth factors such as capital, labor and technological progress on economic growth, the Solow model is used, which is described as a function of production at the expense of (formula):

$$
\mathrm{Y}=\mathrm{F}(\mathrm{K}, \mathrm{L}, \mathrm{E})
$$

$\mathrm{Y}$ - output or gross domestic product,

$\mathrm{K}$ - capital or production assets,

$\mathrm{L}$ - real life business, 
Electronic labor productivity per worker [3].

The sources or factors of production are estimated according to well-known capital and labor models. Solow or financial, financial and labor resources [3].

Variable E represents the level of 'knowledge' accumulated in a labor-saving science and technology progressive society (hereinafter STP) or the quality of human capital that affects the productivity of employees.

The most commonly used products are products multiplied by the properties given by the formula (2):

$$
Y=A \cdot K^{\alpha} \cdot L^{\beta}
$$

where $\mathrm{A}$ is a neutral factor of scientific and technological progress;

$\alpha, \beta$ are the coefficients of expenditure flexibility for fixed capital and labor.

For the function 2010-2020 years of agricultural, forestry and fishing services between economic activity according to the National Statistics Committee of the Ministry of Economy of the Republic of Kazakhstan on the type of products (services), the total volume of investment in fixed assets and use the statistics of the number of workers in the economy of Kazakhstan.

You need to move from dynamic indicators in current prices to comparative values based on the concept of time value of money, because the statistics for each year are not equivalent. Money, inflation, devaluation, etc. in different periods. It has different values under the influence of economic factors. It was "reduced" when comparing economic indicators with comparable prices in accordance with the consumer price index.

In order to measure the actual current economic indicators, it is necessary to "clear" the nominal indicators from the effect of changes in price levels and bring the base money prices to the base period prices, using the coefficient of depreciation of money during the period.

In addition, the transaction must be made before the economic time series is analyzed, which should lead to such a change at all levels of the series. Such a reduction in data on the unit scale is achieved by normalizing the values of each variable in the distribution range. Thanks to this transformation, the analyzed original data can be obtained in dimensionless units

Thus, after the reduction and standardization procedures until 2010, the production function of the increase in GDP of the republic in relation to investment in fixed assets and employment for the period 2010-2020 years was obtained by formula (2):

$$
Y=0,011 \cdot K^{0,952} \cdot L^{0,599}
$$

$\mathrm{Y}$ - Gross output of agricultural, forestry and fishery products (services), mln. tenge;

$\mathrm{K}$ - Investments in fixed assets of agriculture, forestry and fisheries, mln. tenge;

$\mathrm{L}$ - Population working in agriculture, forestry and fisheries, thousand people.

Investment in fixed assets will increase by $1 \%$, gross output by $0.952 \%$, and the number of employees will increase by $0.5 \%$ and $0.599 \%$, because $\alpha>\beta$, then the labor force increases.

Detection factor $=0.923$, which indicates the high quality and adequacy of the obtained mathematical model. In addition, the Fisher test has a significance of $\mathrm{F}<0.05$ and the regression equation is statistically significant with a $95 \%$ probability.

Identification of factors of comprehensive and intensive production.

If products and costs are expressed in comparable units, the scale and efficiency of production can be expressed as a function of production. However, the problem of comparing the current and past labor force has not yet been satisfactorily resolved, so they resort to relatively unmeasured indicators. In these indicators, the product of multiplication is written by the formula (3) as follows:

$$
\frac{Y}{Y_{0}}=\left(\frac{K}{K_{0}}\right)^{\alpha} \cdot\left(\frac{L}{L_{0}}\right)^{\beta}
$$

ere is the value of funds and performance and costs in the base year.

Calculates the productivity and production scale of the production function (2). 
20 of 10 from the standard price of 20101020 Total production since 20208.378 times until, that is, 8.378 times, and investments in fixed assets during the same period increased by a factor of 14601 . 14601 , the number of people working in the economy decreased by 0.561 times, $=0.561$. Flexibility in terms of fixed assets and investment is equal

$$
\gamma=\frac{\alpha}{\alpha+\beta}=0,614, \quad 1-\gamma=\frac{\beta}{\alpha+\beta}=0,386
$$

The value of these coefficients indicates that the total production of goods (services) will increase by $0.614 \%$ with an increase in investment in fixed assets by $1 \%$ and employment by $0.384 \%$.

Since $(A+\beta)>1$, the output increases faster than the average factors.

Now we determine the efficiency of special resources $=0.574$ and $=14,922$.

$$
E_{K}=\frac{\widetilde{Y}}{\widetilde{K}}=0,574 \text { and } E_{L}=\frac{\widetilde{Y}}{\widetilde{L}}=14,922 \text {. }
$$

Then the general indicator of economic efficiency as a geometric value of sections

$$
E=E_{K}^{\gamma} \cdot E_{L}^{1-\gamma}=0,574^{0,614} \cdot 14,922^{0,386}=2,019 \text {. }
$$

We defined scale as a geometric value of resource growth:

$$
M=\widetilde{K}^{\gamma} \cdot \widetilde{L}^{1-\gamma}=14,601^{0,614} \cdot 0,561^{0,38 \cdot=4,149} \text {. }
$$

Thus, between 2007 and 2017, the total growth of gross output (services) of agriculture, forestry and fisheries increased by 4.15 times on a scale of production and by 8.32 times due to increased production efficiency.

There is a close quantitative and qualitatively positive relationship between the dynamics of agricultural subsidies and the gross output and correlation coefficient.

Despite the reduction of subsidies, 20 in total production 20201020 compared to 20 in 4 times.

However, the financing of crop and livestock production is not uniform. State support is an important tool of state regulation of agriculture. The state policy in the field of support of agricultural enterprises is a driving force for the opening of new industries and the opening of the export potential of Kazakhstan's economy. Over the past decade, the country has developed and implemented largescale programs in the Republic of Kazakhstan, such as the Agribusiness Development Program for 2013-2020 and the State Agribusiness Development Program for 2017-2021 [4 ].

In addition, the Ministry of Agriculture has met the forecast funding requirements to achieve the indicative indicators of the state program of agro-industrial complex development for 2017-2021, shown in Table 1.

Table 1 - Estimated need for funding to achieve the indicative indicators of the state program for the development of the agro-industrial complex, mln. Tenge

\begin{tabular}{|l|l|l|l|l|l|l|}
\hline \multicolumn{1}{|c|}{ Measures } & \multicolumn{1}{|c|}{2017} & \multicolumn{1}{c|}{2018} & \multicolumn{1}{c|}{2019} & 2020 & 2021 & \multicolumn{1}{c|}{ All } \\
\hline Necessary funding & 322554 & 362291 & 357356 & 310396 & 272166 & 1624764 \\
\hline including working capital for projects & 44281 & 43186 & 36470 & 29234 & 25193 & 178363 \\
\hline Current assets of agricultural producers & 34919 & 42642 & 42671 & 36334 & 30666 & 187232 \\
\hline Investment funds & 109147 & 197343 & 184290 & 135926 & 81569 & 708275 \\
\hline
\end{tabular}

There is a close quantitative and qualitatively positive relationship between the dynamics of agricultural subsidies and the gross output and correlation coefficient.

Currently, KazAgro Holding implements various loan programs for the development of agriculture in Akmola region for investment projects in animal husbandry and crop production, financed from the national budget and the National Fund. 
State support for agriculture is provided in the following ways.

1) Public funding in the form of direct budget subsidies, the state itself is the largest and most influential market participant: subsidies for the purchase of machinery and equipment for agricultural businesses, interest rates on loans and leases, subsidies for fuels and lubricants, subsidies for goods and materials, herbicides, insurance etc. reducing the cost of production through

2) lending to agricultural producers through the budget-subsidized banking system: the Ministry of Agriculture of the Republic of Kazakhstan and TTBs.

3) Indirect financing from agricultural producers: preferential taxation, interference in goods and supplies, protectionist policies in domestic and foreign markets.

WTO support of farmers, this trade is distorted due to the impact of the measures taken to support the sector, the three "baskets" - "green", "yellow" and "blue" [5].

To determine the investment attractiveness, it is necessary to assess the economic efficiency of existing agricultural producers in accordance with the economic categories.

Table -2 shows the main characteristics of the existing agro-industrial complex by farm categories

\begin{tabular}{|c|c|c|c|}
\hline Indicators & Agricultural enterprises & Farms & Private farms \\
\hline Total number of farms & 12217 & 187900 & $1,645,739$ \\
\hline The size of farms & large & Small and medium & Small \\
\hline $\begin{array}{l}\text { The share of agricultural } \\
\text { production in the gross output of } \\
\text { agricultural products (services), } \%\end{array}$ & 25.7 & 29.7 & 50.1 \\
\hline $\begin{array}{l}\text { The share of agricultural } \\
\text { production in crop production , } \%\end{array}$ & 31.1 & 37.2 & 30.9 \\
\hline $\begin{array}{l}\text { The share of livestock products, } \\
\text { agricultural products, } \%\end{array}$ & 14.4 & 17.0 & 68.6 \\
\hline Total area of agricultural land, ha & $500-10000$ & $50-2000$ & $0.10-0.5$ \\
\hline
\end{tabular}

Gross production of agricultural products (services) by economic categories at current prices in 2020 compared to 2010 shows a high growth rate:

- agricultural enterprises 3.4 times;

- Peasant (farming) farms 4.3 times;

- households 3.7 times.

However, the actual indicators show a significantly lower growth:

- agricultural enterprises 1.5 times;

- Peasant (farmer) farms 1.9 times;

- 1.6 times for households.

Figure 1 shows the regression linear and polynomial relationship between the total agricultural production of legal entities for the period 20102020 - agricultural producers and STB loans.

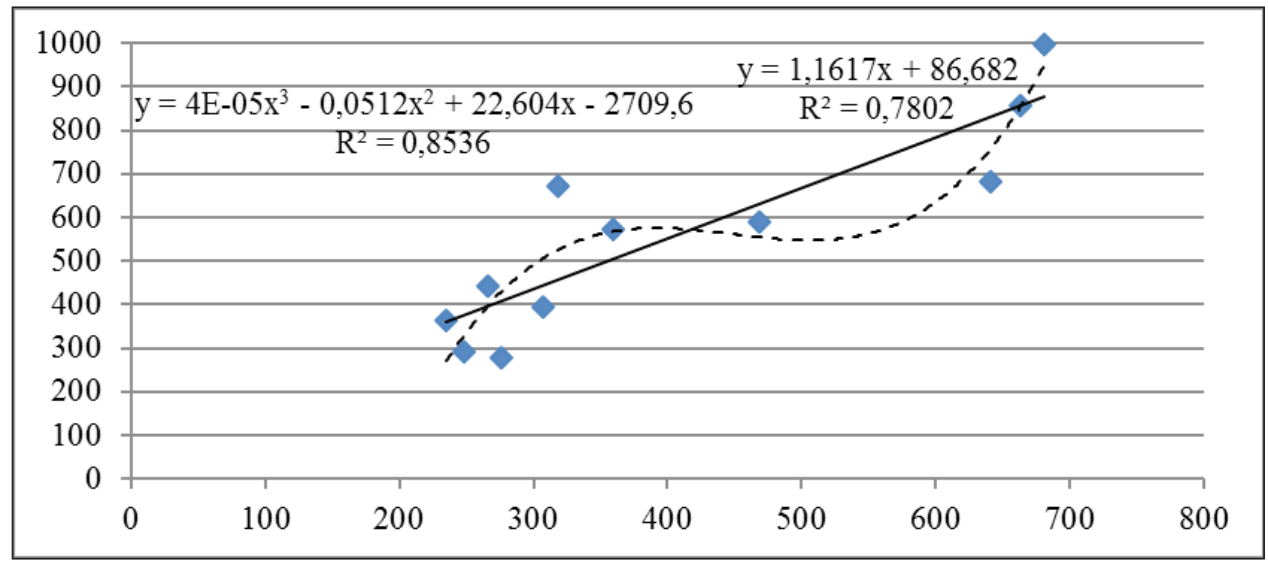

Figure 1 -2010-2020 y. regression relationship between legal entities and total issue of STB loans 
As shown in Figure 1, the share of individuals in the population, such as households and peasants or farms (hereinafter $-\mathrm{K}(\mathrm{F}) \mathrm{X}$ ) is in the range of $2-6 \%$.

The economic efficiency of agricultural production in the form of gross agricultural output is strongly dependent on the volume of loans of tier two banks, and its linear regression equation takes the following form:

$$
y=1,161 x+86,68
$$

The coefficient of 1.161 means that an increase in lending by 1 thousand tenge will lead to an increase in production by 1,161 thousand tenge. There is a positive correlation between the dynamics of lending and investment and gross output. Gross domestic product growth in 2020 was 3.4 times compared to 2010 years.

Figure 2 shows the regression linear and polynomial relationship between the gross output of individuals - peasant (farming) farms and debts of private farms and second-tier banks.

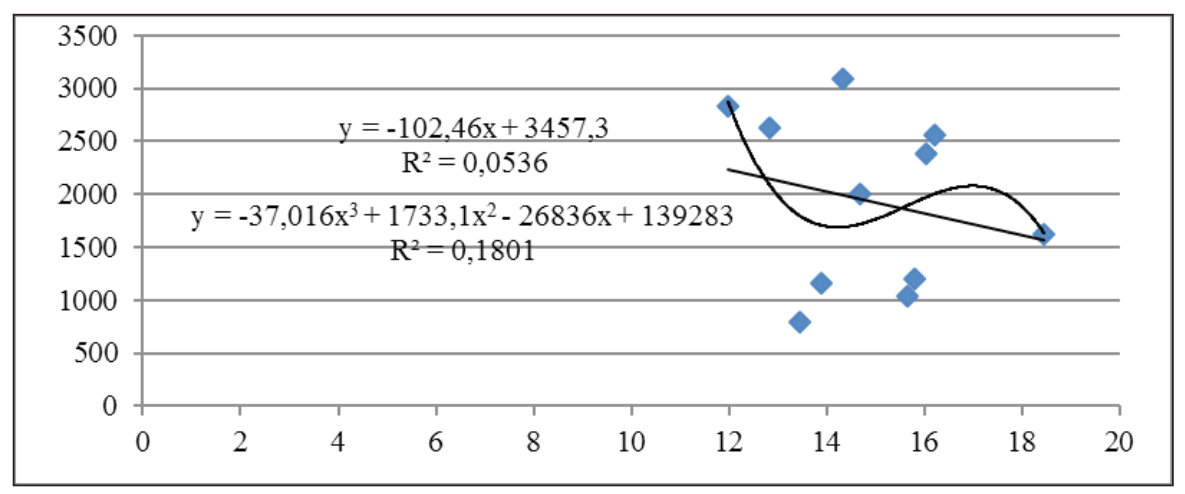

Figure 2 - Regression relationship between the gross product of individuals

In general, the economic efficiency of agricultural production and the national economy is inversely related to the amount of loans received from tier two banks with a correlation coefficient, and the linear regression equation is as follows:

$$
Y=-102,41 x+3457
$$

That is, despite the very low level of lending, it can be concluded that the results of financial and economic activities of farms and farms show a positive trend. At the same time, their growth rate is 3.8 times higher than the growth of gross output of agricultural producers in 2020 compared to 2010 years, which is still higher than that of agricultural producers.

\section{Conclusions and recommendations}

The purpose of the strategic plans of the state regional policy is to reduce the gaps in the level of socio-economic development between the regions through the implementation of priority investment projects that contribute to the economic, social and cultural development of the regions and improve living standards.

The balanced development of the regions is a major global trend. Each country has relatively prosperous and backward regions - these are natural regional differences related to socio-economic, natural, climatic, resource and other conditions. In this context, the task of the state is to prevent excessive regional differentiation. 


\title{
REFERENCES
}

1 Finance Money and credit: textbook. manual [Text] / Ed. В.К. Сенчагова, А.И. Arkhipova. - М.: Prospect, 2017. $-650 \mathrm{p}$.

2 Finance, money supply and credit: textbook. manual [Text] / Ed. N.F. Samsonova. - M .: INFRA-M, 2016. $-236 \mathrm{p}$.

3 Finance, money supply and credit: textbook. for universities [Text] / Under ed. M.V. Romanovskogo, OV Vrublevskaya. - M.: Yurait - M., 2014. - 450 p.

4 Solow RM Technical change and general production function // Review of Economics and Statistics. 1957. - August 39, Volume 3- P. 312-320.

5 The state program of development of agro-industrial complex of the Republic of Kazakhstan for 2017 2021. - Resolution of the Government of the Republic of Kazakhstan. - dated July 12, 2018. - No. 423.

\author{
А.А. АМАНБАЕВА,,$* 1$ \\ $\mathrm{PhD}$. \\ *e-mail: asema.31.1983@mail.ru
}

М.К. ТОЛЫМГОЖИНОВА, ${ }^{2}$

Э.Ғ.К.

e-mail: maigylt@mail.ru

С.А. АЗЫЛКАНОВА, ${ }^{3}$

Э.Ғ.К.

e-mail: azsaule@mail.ru

ЛИ ЧОН КУ,

э.Ғ.к., доцент.

e-mail: tchonli@yahoo.com

${ }^{1}$ Қазақ инновациялық гуманитарлық-заң университеті, Казақстан, Семей қ.

${ }^{2}$ Шәкәрім атындағы Семей мемлекеттік университеті, Казақстан, Семей қ.

3 Л.Н. Гумилев атындағы Еуразия ұлттық университеті, Казақстан, Нұр-Сұлтан қ.

${ }^{4}$ Янки Купалы атындағы Гродно мемлекеттік университеті, Беларусь, Гродно қ.

\section{ӨНІРГЕ ИНВЕСТИЦИЯЛЫК РЕСУРСТАРДЫ ТАРТУ ТИІМДІЛІГІН ТАЛДАУ ЖӘНЕ БАҒАЛАУ}

\begin{abstract}
Андатпа
Мақаланың мақсаты - өңірлердің инвестициялық белсенділігін бағалау әдістемесін ұсыну. Аймақтың экономикалық саясатын макроэкономикалық деңгейде мемлекет өзінің басқару органдары, заң шығарушы және атқарушы билік органдары арқылы жүзеге асырады. Осы жоғары деңгейде ұлттық экономиканы және әрбір өңірді дамыту жөніндегі шешімдер ұлттық мүдделерді ескере отырып қабылданады. Сонымен бірге, ұлттық экономиканы тек бірлік ретінде ғана емес, сонымен бірге әртүрлі қатынастарда бір-бірінен ерекшеленетін және бірге жұмыс істейтін жүйе ретінде қарастыру қажет. Бұл жүйеде нақты аумаққа қарамастан, олар бүкіл елдің өндірістік және экономикалық әлеуетін, оның әлемдік экономикалық кеңістіктегі орнын, ұлттық және экономикалық қауіпсіздік пен ұлттық экономиканың тұрақтылығын анықтайды. Бұл әскери-өнеркәсіптік кешен, бәсекеге қабілетті, ауқымды ғылыми және жоғары технологиялық өндірістер, маңызды мәдени және әлеуметтік нысандар. Бұл объектілердің дамуын реттеу - бұл мемлекеттік аймақтық экономикалық саясаттың жоғары деңгейдегі негізгі бағыты. Өңірлік экономиканы реттеуге жалпы мемлекеттік көзқарас тұтастай алғанда елдегі әлеуметтік әділеттілікті қамтамасыз ету мүдделеріне де жауап береді. Бұл өз кезегінде әртүрлі себептермен немесе үкіметтердің шешімдерін негіздеу үшін әлеуметтік артта қалған аймақтар халқының өмір сүру деңгейін жақсарту үшін арнайы бағдарламалар әзірлеуді талап етеді. Мұндай бағдарламалар бұрын Қазақстанның ауылдық жерлерінде әзірленген болатын, бірақ кейбіреулері олардың іске асырылуына қанағаттанбайды.
\end{abstract}

Тірек сөздер: экономика, инвесициялар, аймақ, арнайы бағдарлама, бағалау, талдау, даму, реттеу. 


\author{
A.A. АМАНБАЕВА, *1 \\ $\mathrm{PhD}$. \\ *e-mail: asema.31.1983@mail.ru \\ М.к. ТОЛЫМГОЖИНОВА, ${ }^{2}$ \\ К.э.Н. \\ e-mail: maigylt@mail.ru \\ С.А. АЗЫЛКАНОВА, ${ }^{3}$ \\ К.э.Н. \\ e-mail: azsaule@mail.ru \\ ЛИ ЧОН КУ, ${ }^{4}$ \\ к.э.н., доцент. \\ e-mail: tchonli@yahoo.com \\ ${ }^{1}$ Казахский гуманитарно-юридический инновационный \\ университет, Казахстан, г. Семей \\ ${ }^{2}$ Семипалатинский государственный \\ университет им. Шакарима, Казахстан, г. Семей \\ ${ }^{3}$ Евразийский национальный университет \\ им. Л.Н. Гумилева, Казахстан, г. Нур-Султан \\ ${ }^{4}$ Гродненский государственный \\ университет им. Янки Купалы, Беларусь, г. Гродно
}

\title{
АНАЛИЗ И ОЦЕНКА ЭФФЕКТИВНОСТИ ПРИВЛЕЧЕНИЯ ИНВЕСТИЦИОННЫХ РЕСУРСОВ В РЕГИОН
}

\begin{abstract}
Аннотация
Цель статьи - представить методику оценки инвестиционной активности регионов. Экономическая политика региона на макроэкономическом уровне осуществляется государством через его органы управления, законодательную и исполнительную ветви власти. На этом высоком уровне решения по развитию национальной экономики и каждого региона принимаются с учетом национальных интересов. При этом необходимо рассматривать национальную экономику не только как единое целое, но и как систему. В этой системе, независимо от конкретной территории, определяют производственный и экономический потенциал всей страны, ее место в мировом экономическом пространстве, национальную и экономическую безопасность и стабильность национальной экономики. Это военно-промышленный комплекс, конкурентоспособные, масштабные научные и высокотехнологичные производства, важные культурные и социальные объекты. Регулирование развития этих объектов является основным направлением государственной региональной экономической политики на высшем уровне. Общегосударственный подход к регулированию региональной экономики также отвечает интересам обеспечения социальной справедливости в стране в целом. Это, в свою очередь, требует разработки специальных программ для повышения уровня жизни населения социально отсталых регионов по разным причинам или для обоснования решений правительств. Такие программы были разработаны в сельской местности Казахстана в прошлом, но некоторые не удовлетворены их реализацией.
\end{abstract}

Ключевые слова: экономика, инвестиции, регион, специальная программа, оценка, анализ, развитие, регулирование. 